\title{
Functionalization of textile materials with bioactive polymeric systems based on propolis and cinnamon essential oil
}

\author{
DOI: 10.35530/IT.071.02.1793
}

LAURA CHIRILĂ

GABRIELA CRISTINA CONSTANTINESCU

ANGELA DANILA

ALINA POPESCU

ROXANA RODICA CONSTANTINESCU

IRINA-MARIANA SĂNDULACHE

\section{ABSTRACT - REZUMAT}

Functionalization of textile materials with bioactive polymeric systems based on propolis and cinnamon essential oil

In order to obtain the textile materials with potential for use in the treatment of inflammatory skin conditions, this study approached the laboratory experiments related to depositing by padding of oil-in-water emulsions type based on chitosan-propolis-cinnamon essential oil. In this regard, seven experimental variants of emulsions were prepared and then characterized by specific methods from physical-chemical and stability point of view. The chitosan-propoliscinnamon essential oil-based emulsions were then immobilized on a knitted textile structure from $100 \%$ organic cotton. The functionalized textile materials were characterized from morphological and antibacterial activity point of view. $\mathrm{pH}$ values obtained for the synthesized polymeric systems were in the range 4.67-4.88 and electrical conductivity of the emulsions increases with the concentration of the hydrophilic phase in the system, the highest values were registered for the emulsion code R4CSP developed with the smallest volume fraction of water. The stability index over a period of 10 days indicated that emulsions are stable, not showing the presence of one of the flocculation, creaming / sedimentation, coalescence or Ostwald ripening phenomena. The highest values of emulsifying activity index were obtained for the R7CSP, emulsion developed with the smallest volume fraction of water. The highest value of viscosity was obtained for the experimental variant R4CSP in which the highest volume fraction of chitosan and the smallest volume fraction of water were used. The textile materials treated with synthesized emulsions based on chitosanpropolis-cinnamon essential oil have antibacterial effect against the $S$. aureus test strain, with inhibition zones between $1.5 \mathrm{~mm}$ (R2CSP and R7CSP) and $4 \mathrm{~mm}$ (R6CSP).

Keywords: functionalized textiles, bioactive compounds, chitosan, cinnamon essential oil, propolis

\section{Funcționalizarea materialelor textile cu sisteme polimerice bioactive pe bază de propolis și ulei esențial} de scorțișoară

Pentru a obține materiale textile cu potențial de utilizare în tratamentul afecțiunilor inflamatorii ale pielii, acest studiu a abordat experimentări de laborator cu privire la depunerea prin metoda fulardării a emulsiilor de tipul ulei-în-apă, pe bază de chitosan-propolis-ulei esențial de scorțișoară. În acest sens, au fost preparate șapte variante experimentale de emulsii și apoi caracterizate prin metode specifice din punct de vedere fizico-chimic și al stabilității. Emulsiile pe bază de chitosan-propolis-ulei esențial de scorțișoară au fost apoi imobilizate pe o structură textilă tricotată din $100 \%$ bumbac organic. Materialele textile funcționalizate au fost caracterizate din punct de vedere morfologic și al activității antibacteriene. $\mathrm{pH}-\mathrm{ul}$ sistemelor bioactive este cuprins între 4,67 si 4,88; conductivitatea electrică crește odată cu concentrația fazei hidrofile, cele mai mari valori înregistrându-se pentru proba cod R4CSP, care conține cea mai mică fracție volumică de apă. Indicele de stabilitate analizat pe o durată de 10 zile a indicat faptul că emulsiile sunt stabile, neindicând prezența unuia dintre fenomenele de floculare, cremare/sedimentare, coalescență sau maturare Ostwald. Valorile cele mai mari ale indicelui activității emulgatoare au fost obținute pentru R7CSP, emulsia realizată cu cea mai mică fracție volumică de apă. Cea mai mare valoare a viscozității a fost obținută pentru varianta experimentală $R 4 C S P$, în care a fost utilizată cea mai mare fracție volumică de chitosan și cea mai mică fracție volumică de apă. Materialele textile tratate cu emulsiile sintetizate pe bază de chitosan-propolis-ulei esențial de scorțișoară prezintă efect antibacterian împotriva tulpinii test S. aureus, cu zone de inhibiție cuprinse între 1,5 mm (R2CSP și R7CSP) și $4 \mathrm{~mm}$ (R6CSP).

Cuvinte-cheie: textile funcționalizate, compuși bioactivi, chitosan, ulei esențial de scorțișoară, propolis

\section{INTRODUCTION}

The development of multifunctional textile materials based on nano- and micro-technologies represents one of the most competitive and dynamic areas of research worldwide, being a major factor in the sustainable development of the textile industry [1]. The design of biopolymeric matrices for the delivery of bioactive compounds constitutes a science-based strategy to provide textile materials with the multifunctional properties [2-3]. Natural compounds derivatives from plants can demonstrate various biological effects, including antibacterial and antifungal activity, anti-inflammatory and antioxidant effects [4]. 
Essential oils have gained new interest in several areas of interest. As natural products they have physico-chemical characteristics that are friendly to the environment with added value. It also possesses a relevant biological activity, being used in the medical field thanks to their biocidal activity (bactericides, virucides and fungicides) and medicinal properties.

Cinnamon (Cinnamomum zeylanicum) essential oil has been widely applied in food products-and it benefits health in various ways due to its antioxidant and antimicrobial properties [5-6]. Furthermore, cinnamon essential oil has gained popularity for use in skin care products, research on its effects on human skin is largely scarce. The major active components of cinnamon essential oil taken from the bark are cinnamaldehyde, eugenol, carvacrol and linalool. A study [7] conducted on human keratinocytes demonstrated the antioxidant effect of cinnamaldehyde, as well as its potential for treating skin disorders. Using essential oils as bioactive compounds is limited due to their low solubility, instability against environmental conditions and susceptibility to oxidative degradation, resulting in the loss of the functional properties [8-9]. Embedding the biologically active components into polymeric matrices is a procedure studied over the last decades worldwide and can provide an ideal solution for achieving a controlled and targeted delivery of the essential oil [10-11]. The polymer is used as protective carrier for the bioactive compound during the transfer until it is released.

Propolis, a natural resinous product, is widely known by its high composition of bioactive compounds and largely used in folk medicine. Propolis has diverse biological activities: it shows antibacterial, antiinflammatory, free radical scavenging, antioxidant, and antitumor effects. The wealth of its bioactive components determines its application in medicine and dentistry as well as in the pharmaceutical, cosmetics, and food industries. Previous studies have shown that propolis is effective in healing wounds and various skin injuries. Propolis is used in the local treatment of burns as an antibacterial, deodorant, anesthetic and stimulant of the regenerative process, forming on the surface of wounds or scars a protective layer, which protects the wound and allows the healing process to begin from its depth.

The aim of the study was to develop textile materials with functional properties by applying bioactive polymeric systems based on chitosan-propolis-cinnamon essential oil. For this purpose, the formulations experiments of bioactive polymeric systems - oil-in-water (O/W) type emulsions have been carried out. The aim was to identify the main factors influencing the formulation process and the stability of the new developed emulsions.

\section{EXPERIMENTAL PART}

\section{Materials}

Chitosan with low molecular weight, $85 \%$ deacetylation degree (Fluka Chemie $\mathrm{GmbH}$, Switzerland) was used as an embedding agent of bioactive agents. Chitosan flakes were dissolved in solution of $\mathrm{CH}_{3} \mathrm{COOH}$ (96\%) (Consors, Romania). Tween 80 (Sigma Aldrich, Germany) was used as a surfactant with emulsifying role and glycerol (Honeywell, USA) has been used as a solubilizing with wetting role. Cinnamon leaf essential oil (Mayam, Romania) and propolis tincture (Larix SA, Romania) $70 \%$ ethanol solution were used as bioactive agents. For preparation of bioactive systems, the distilled water has been used. Bleached $100 \%$ knitted organic cotton was used for the functionalization processes.

\section{Emulsion preparation methodology}

For the achievement of the bioactive systems, initially stock solutions of $3 \%$ chitosan in $2 \% \mathrm{CH}_{3} \mathrm{COOH}$ and $30 \%$ Tween 80 solution were prepared. Further, over the previously prepared chitosan solution, distilled water was added dropwise, under continuous stirring until a homogeneous mixture was obtained. Glycerol was added to the chitosan/water system, and the system was maintained under magnetic stirring for 10 minutes, after which Tween 80 emulsifier was added. After complete homogenization of the solution, the propolis and cinnamon essential oil were separately added, maintaining the magnetic stirring for 10 minutes for each stage.

The stages of obtaining emulsions based on chitosan-propolis-cinnamon essential oil are shown in figure 1.

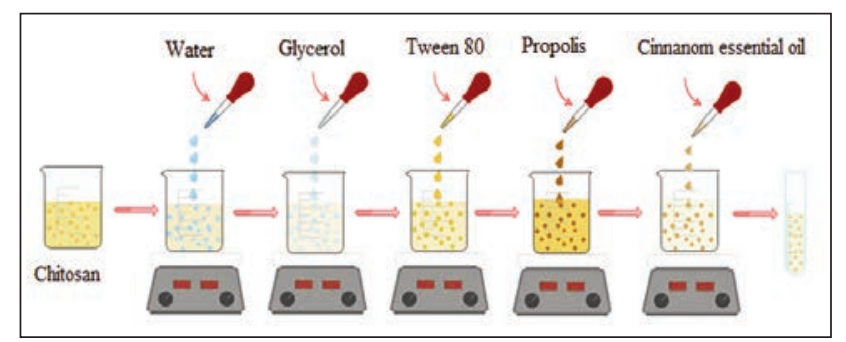

Fig. 1. The stages of obtaining emulsions based on chitosan-propolis-cinnamon essential oil

Thus, 7 variants of emulsions have been developed that differ by: i) the concentration of the embedding agent (chitosan), ii) the concentration of the selected bioactive compounds. For all experimental variants, the ratio between the two selected bioactive compounds was kept constant. The selected experimental variants are presented in table 1.

\section{Immobilization of bioactive polymeric systems on the textile materials}

The 7 experimental variants were immobilized on the textile materials by the padding method on the laboratory padder (ROACHES, UK). The treated textile materials were then subjected to the drying operation at $50^{\circ} \mathrm{C}$ for 3 minutes. Subsequently, the textile materials were analysed from morphological and antibacterial activity point of view. 

activity: The antibacterial COMPOSITION OF THE EMULSIONS (REPORTED OF 30 ML EMULSION)

\begin{tabular}{|c|c|c|c|c|c|c|}
\hline Code & $\begin{array}{c}\text { Chitosan } \\
(\mathbf{m l})\end{array}$ & $\begin{array}{c}\text { Tween } \mathbf{8 0} \\
(\mathbf{m l})\end{array}$ & $\begin{array}{c}\text { Glycerol } \\
(\mathbf{m l})\end{array}$ & $\begin{array}{c}\text { Distilled } \\
\text { water }(\mathbf{m l})\end{array}$ & $\begin{array}{c}\text { Essential } \\
\text { oil }(\mathbf{m l})\end{array}$ & $\begin{array}{c}\text { Propolis } \\
(\mathbf{m l})\end{array}$ \\
\hline R1CSP & 9 & 0.5 & 2.7 & 16 & 0.9 & 0.9 \\
\hline R2CSP & 12 & 0.5 & 2.7 & 13.0 & 0.9 & 0.9 \\
\hline R3CSP & 15 & 0.5 & 2.7 & 10.0 & 0.9 & 0.9 \\
\hline R4CSP & 18 & 0.5 & 2.7 & 7.0 & 0.9 & 0.9 \\
\hline R5CSP & 15 & 0.5 & 2.7 & 11.2 & 0.3 & 0.3 \\
\hline R6CSP & 15 & 0.5 & 2.7 & 10.6 & 0.6 & 0.6 \\
\hline R7CSP & 15 & 0.5 & 2.7 & 9.4 & 1.2 & 1.2 \\
\hline
\end{tabular}
activity of the treated samples in different variants was qualitatively assessed by Agar diffusion method according with the SR EN ISO 20645:2005 standard - Determination of antibacterial activity-agar diffusion plate test, by using of cultures in liquid medium replicated at 24 hours of ATCC 6538 Staphylococcus aureus test strains (Gram-

\section{Methods}

Optical microscopy: The emulsions prepared according to the working recipes were analysed microscopically using an OLYMPUS BX51 optical microscope (Philippines) equipped with the OLYMPUS UC30 photo digital camera.

$\mathrm{pH}$ determination: Emulsion $\mathrm{pH}$ was directly measured using a HANNA portable $\mathrm{pH}$-meter immersed in the prepared undiluted emulsions. The measurements were performed in triplicate.

Conductometric analysis: The conductivity of the analyzed emulsions was measured directly, using the Consort conductometer, model C1020 WTW (TARA), with SP10T electrode. The conductivity values represent the average of 3 successive readings made on the same sample.

Determination of the emulsion stability index: The stability of an emulsion can be appreciated immediately after preparation and/or after a certain period of time. Immediately after preparation, the emulsions were introduced into test tubes and the evolution was followed for 10 days after their preparation. The stability of the emulsions was evaluated by determining the stability index (ESI) using the equation (1):

$$
E S I(\%)=[H-(H s+H c)] / H
$$

where $H$ is the initial height of the emulsion $(\mathrm{cm})$, $\mathrm{Hs}$ - the height of the serous layer $(\mathrm{cm}), \mathrm{Hc}$ - the height of the creamy layer (cm).

Turbidity analysis: In order to determine the turbidity, the transmittance was determined, using a Camspec M501 UV-VIS Spectrophotometer. Turbidity was calculated with the equation (2):

$$
\tau=2.303 \cdot A / L
$$

where $\tau$ is turbidity $\left(\mathrm{cm}^{-1}\right), A-$ absorbance, $L-$ path length of cuvette $(\mathrm{cm})$.

Viscosity determination: The viscosity measurements of the obtained bioactive systems were performed with the DV2T Brookfield AMETEK viscometer. Measurements were performed in triplicate.

Electron microscopy: Visualization of the morphology of the cotton fiber surfaces treated with the bioactive systems was performed by scanning electron microscopy using the Quanta 200 electron microscope (FEl, The Netherlands). positive) and ATCC 11229 Escherichia coli (Gramnegative) test strains. Firstly, the Manitol Salt Agar gel for Staphylococcus aureus and Nutrient Agar gel for Escherichia coli were prepared for the lower layer without bacteria. Thus, $10 \pm 0.1 \mathrm{ml}$ gel was placed into each sterilized Petri dish and allow gel to solidify. Another amount of gel was prepared for the upper layer and cooled to $45^{\circ} \mathrm{C}$ in a water bath. $150 \mathrm{ml}$ of gel is inoculated with $1 \mathrm{ml}$ of bacterial working solution $1-5 \times 10^{8} / \mathrm{ml}$. The container is vigorously stirred for the uniform distribution of bacteria. The quantity of $5 \pm 0.1 \mathrm{ml}$ are introduced in each Petri plates and allow the gel to solidify. The textile specimens $(2 \mathrm{~cm}$ diameter) are placed on the surface of the nutrient medium and then incubated at $37^{\circ} \mathrm{C}$ for $24 \mathrm{~h}$. The antibacterial evaluation was based on the absence or presence of bacterial multiplication in the contact area between the agar and the test specimen and on the occurrence of a possible inhibition area around the specimens. Inhibition zones were calculated using the following equation (3):

$$
H=(D-d) / 2
$$

where $H$ is the inhibition zone $(\mathrm{mm}), D$ - the total diameter of specimen and inhibition zone $(\mathrm{mm}), d-$ the diameter of specimen $(\mathrm{mm})$.

The evaluation of the results obtained after the calculation of the inhibition zones was performed according to the criteria from SR EN ISO 20645:2005 standard, depicted in the table 2.

\begin{tabular}{|c|c|}
\hline \multicolumn{2}{|c|}{ Table 2} \\
\hline \multicolumn{3}{|c|}{ PCRITERIA FOR EVALUATION OF INHIBITION ZONES } \\
ACCORDING TO THE \\
\begin{tabular}{|c|c|c|}
\hline $\begin{array}{c}\text { Inhibition zone } \\
(\mathbf{m m})\end{array}$ & Growth & Evaluation \\
\hline$>1$ & $\begin{array}{l}\text { absent } \\
\text { absent } \\
\text { absent } \\
0\end{array}$ & Satisfactory effect \\
\hline 0 & low & Efficiency limit \\
\hline 0 & $\begin{array}{l}\text { moderate } \\
\text { important }\end{array}$ & Unsatisfactory effect \\
\hline 0
\end{tabular}
\end{tabular}




\section{RESULTS AND DISCUSSION}

\section{Emulsions appearance}

From the visual analysis it is observed that, the emulsions prepared are presented in the form of homogeneous white-yellow-milky solutions without particle agglomerations throughout the sample mass. The images obtained by optical microscopy for the 7 experimental variants are shown in figure 2 . According to microscopic images, the dispersed molecule phase is presented as a compact, dense small globule mass. Normally, the destabilization of the emulsions begins with the drops flocculation of essential oil followed by the phenomenon of coalescence and formation of two distinct phases (separation).

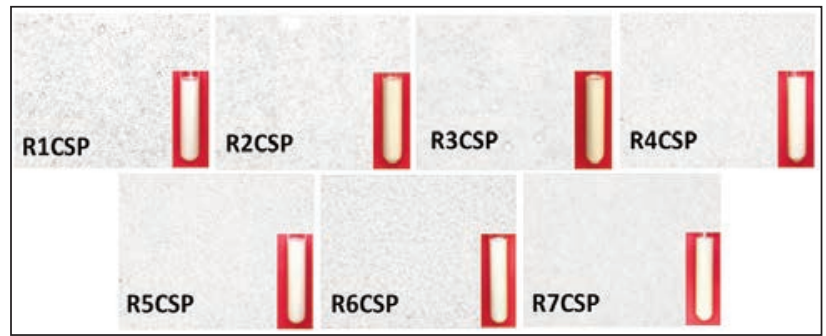

Fig. 2. Optical microscopy of the resulted bioactive systems

\section{Physical-chemical analysis of emulsions}

The $\mathrm{pH}$ and conductivity values recorded for the synthesized polymeric systems are presented in table 3 . Analyzing comparatively the $\mathrm{pH}$ values obtained for the synthesized polymeric systems (table 3 ) it can be seen that they are in the range 4.67-4.88. It can also be observed that the addition of a higher quantity of active principle (essential oil and propolis) causes a lower acid $\mathrm{pH}$. The electrical conductivity of the emulsions increases with the concentration of the hydrophilic phase in the system, highest values registered the for the emulsion developed with the smallest volume fraction of water (e.g. R4CSP). There is no linear dependence between the values of conductivity and the volume fraction of essential oil.

\section{Emulsions stability}

The calculated values for the stability index, are shown in table 4 . The values recorded for the stability index over a period of 10 days indicate that they were stable, during this time not showing the presence of one of the flocculation, creaming/sedimentation, coalescence or Ostwald ripening phenomena. Generally, the turbidity of the bioactive polymeric systems is correlated to a great extent with their stability. Analysing the values obtained for the 7 experimental variants (table 4) it can be observed that the lowest values of the turbidity were obtained for the R5CSP variant (1.81) in which the smallest amount of active principle is also present (essential oil and propolis). Turbidity decreases with increasing particle size of emulsion.

\section{UV-VIS analysis}

The UV-VIS spectra recorded for the obtained polymeric systems are shown in figure 3 . UV-vis spectra revealed the presence of absorption bands in the 220-290 nm UV range. The analysed emulsions are characterized by intense absorption in the 270-290 $\mathrm{nm}$ area. The major peak in this area is very close to the maximum absorption (286 $\mathrm{nm}$ ) obtained for cinnamaldehyde, the majority compound present in the cinnamon essential oil [12].

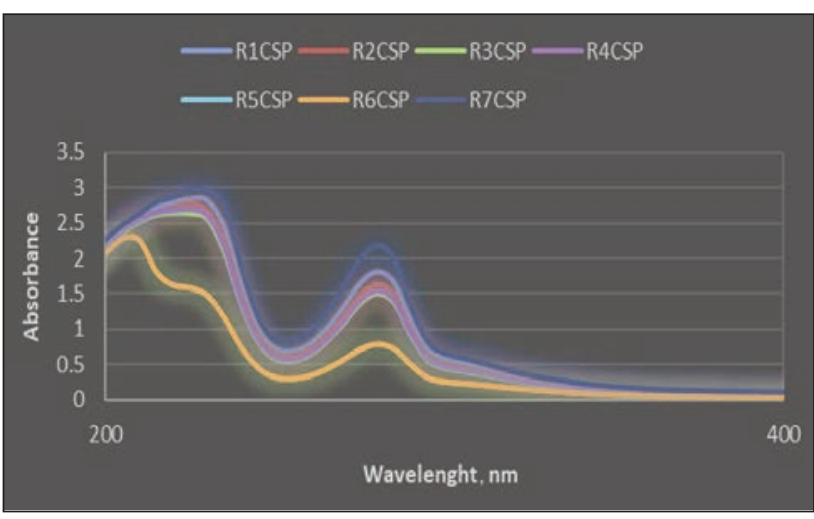

Fig. 3. UV-VIS spectra recorded for the chitosanpropolis-cinnamon essential oil systems

\begin{tabular}{|c|c|c|c|c|c|c|c|}
\hline \multicolumn{8}{|c|}{ CONDUCTIVITY AND pH OF BIOACTIVE SYSTEMS } \\
\hline \multirow{2}{*}{ Parameters measured } & \multicolumn{7}{|c|}{ Code } \\
\hline & R1CSP & R2CSP & R3CSP & R4CSP & R5CSP & R6CSP & R7CSP \\
\hline $\mathrm{pH}$ & 4.67 & 4.68 & 4.67 & 4.83 & 4.84 & 4.86 & 4.88 \\
\hline Conductivity $(\mathrm{m} \cdot \mathrm{S} / \mathrm{cm})$ & 1.24 & 1.54 & 1.84 & 2.20 & 2.01 & 1.99 & 1.78 \\
\hline
\end{tabular}

\begin{tabular}{|c|c|c|c|c|c|c|c|}
\hline \multicolumn{1}{|c|}{ STABILITY OF EMULSIONS } \\
\hline Stability & R1CSP & R2CSP & R3CSP & R4CSP & R5CSP & R6CSP & R7CSP \\
\hline Turbidity $\left(\mathrm{cm}^{-1}\right)$ & 4.184 & 3.762 & 3.484 & 3.562 & 1.816 & 1.956 & 5.024 \\
\hline Stability index $(\%)$ & 100 & 100 & 100 & 100 & 100 & 100 & 100 \\
\hline
\end{tabular}


The main viscosity indices recorded for the synthesized emulsions are shown in table 5 .

From the comparative analysis of the viscosities values it is observed that the highest value was obtained for the experimental variant R4CSP $(237.5 \mathrm{cP})$ in which the highest volume fraction of chitosan and the smallest volume fraction of water (R4CSP) were used. It can also be observed that the viscosity of the system is not dependent on the volume fraction of active principle (propolis and essential oil), the highest amount of active principle in the system

\begin{tabular}{|c|c|c|c|c|c|}
\hline \multicolumn{2}{|c|}{ VISCOSITY INDICES RECORDED FOR THE EMULSIONS } \\
\hline Code & $\begin{array}{c}\text { Viscosity } \\
\text { (cP) }\end{array}$ & $\begin{array}{c}\text { SS } \\
\left(\text { dyne/cm }^{2}\right)\end{array}$ & $\begin{array}{c}\text { SR } \\
\left(\mathbf{s}^{-1}\right)\end{array}$ & $\begin{array}{c}\text { Speed } \\
\text { (RPM) }\end{array}$ & $\begin{array}{c}\text { Temperature } \\
\left({ }^{\circ} \text { C) }\right.\end{array}$ \\
\hline R1CSP & 57.16 & 106.36 & 186 & 200 & 25.33 \\
\hline R2CSP & 95.16 & 177.03 & 186 & 200 & 25.33 \\
\hline R3CSP & 151.13 & 281.03 & 186 & 200 & 25.4 \\
\hline R4CSP & 237.5 & 441.8 & 186 & 200 & 25.3 \\
\hline R5CSP & 133.1 & 247.53 & 186 & 200 & 25.43 \\
\hline R6CSP & 147.86 & 274.96 & 186 & 200 & 25.53 \\
\hline R7CSP & 126.2 & 243.7 & 186 & 200 & 25.76 \\
\hline
\end{tabular}
(R7CSP, $\varphi=0.08 \mathrm{ml}$ active principle $/ \mathrm{ml}$ emulsion) leading to obtaining of a viscosity with comparable values to those obtained when using smaller volume fractions $(\varphi=0.06 \mathrm{ml}$ oil $/ \mathrm{mL}$ emulsion, $\varphi=0.04 \mathrm{ml}$ oil $/ \mathrm{mL}$ emulsion). The shear stress (SS) has the highest value in the case of the R4CSP variant, the variant obtained when using the largest volume fraction of chitosan, respectively the smallest volume fraction of water.

\section{Electron microscopy of textile materials functionalized with bioactive systems}

The images obtained at a magnification of $\times 8000$ for knitted textiles treated with bioactive systems are shown in figure 4 . The resulting micrographs reveal that the surface of the cotton fibers is covered with a thin polymeric layer deposited both on the surface of the fibers and inside the space between the fibers. However, the micrographs cannot provide information about the thickness of the deposited layer and its uniformity.

\section{Assessment of antibacterial activity}

Images of Petri plates after $24 \mathrm{~h}$ incubation are shown in figure 5 and assessment of antibacterial activity is shown in table 6.

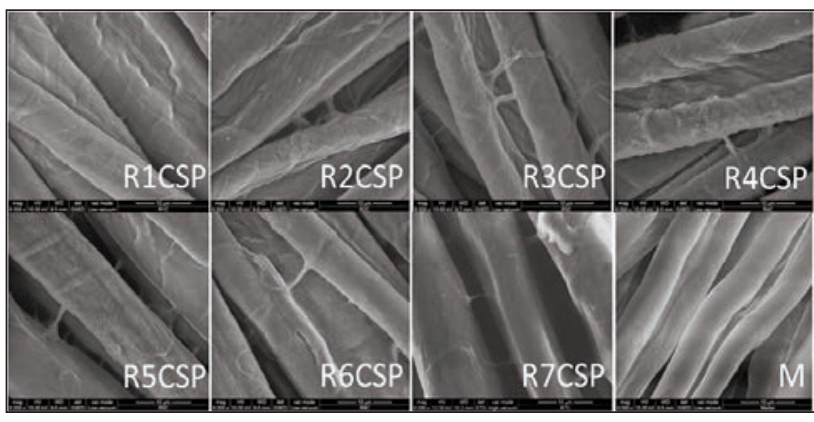

Fig. 4. Electronic images recorded for the knitted fabrics treated with chitosan-propolis-cinnamon essential oil polymeric system

By analyzing the obtained results it can be concluded that the textile materials treated with synthesized emulsions based on chitosan-propolis-cinnamon essential oil have antibacterial effect against the $S$. aureus test strain, with inhibition zones between $1.5 \mathrm{~mm}$ (R2CSP and R7CSP) and $4 \mathrm{~mm}$ (R6CSP). In the case of $E$. coli strain, the presence of the inhibition zone and the growth of the test strain in the whole culture medium were not observed, being considered a satisfactory effect in terms of antibacterial activity. There is no correlation between the amount of active principle and the obtained antibacterial effect, the sample treated with the emulsion with the

\begin{tabular}{|c|c|c|c|c|}
\hline \multicolumn{4}{|c|}{ EVALUATION OF THE ANTIBACTERIAL ACTIVITY } \\
\hline \multirow{2}{*}{ Code } & \multicolumn{2}{|c|}{ E. coli } & \multicolumn{2}{c|}{ S. aureus } \\
\cline { 2 - 5 } & Inhibition zone (mm) & Evaluation & Inhibition zone $(\mathbf{m m})$ & Evaluation \\
\hline R1CSP & $-\left(^{*}\right)$ & Satisfactory effect & $-\left(^{*}\right)$ & Satisfactory effect \\
\hline R2CSP & $-\left(^{*}\right)$ & Satisfactory effect & 1.5 & Satisfactory effect \\
\hline R3CSP & $-\left(^{*}\right)$ & Satisfactory effect & $-\left(^{*}\right)$ & Satisfactory effect \\
\hline R4CSP & $-\left(^{*}\right)$ & Satisfactory effect & 2.5 & Satisfactory effect \\
\hline R5CSP & $-\left(^{*}\right)$ & Satisfactory effect & 3 & Satisfactory effect \\
\hline R6CSP & $-\left(^{*}\right)$ & Satisfactory effect & 4 & Satisfactory effect \\
\hline R7CSP & $-\left(^{*}\right)$ & Satisfactory effect & 1.5 & Unsatisfactory effect \\
\hline M & $-\left(^{*}\right)$ & Unsatisfactory effect & $-\left(^{*}\right)$ & \\
\hline
\end{tabular}

$\left(^{*}\right)$ No inhibition zone, no multiplication. 


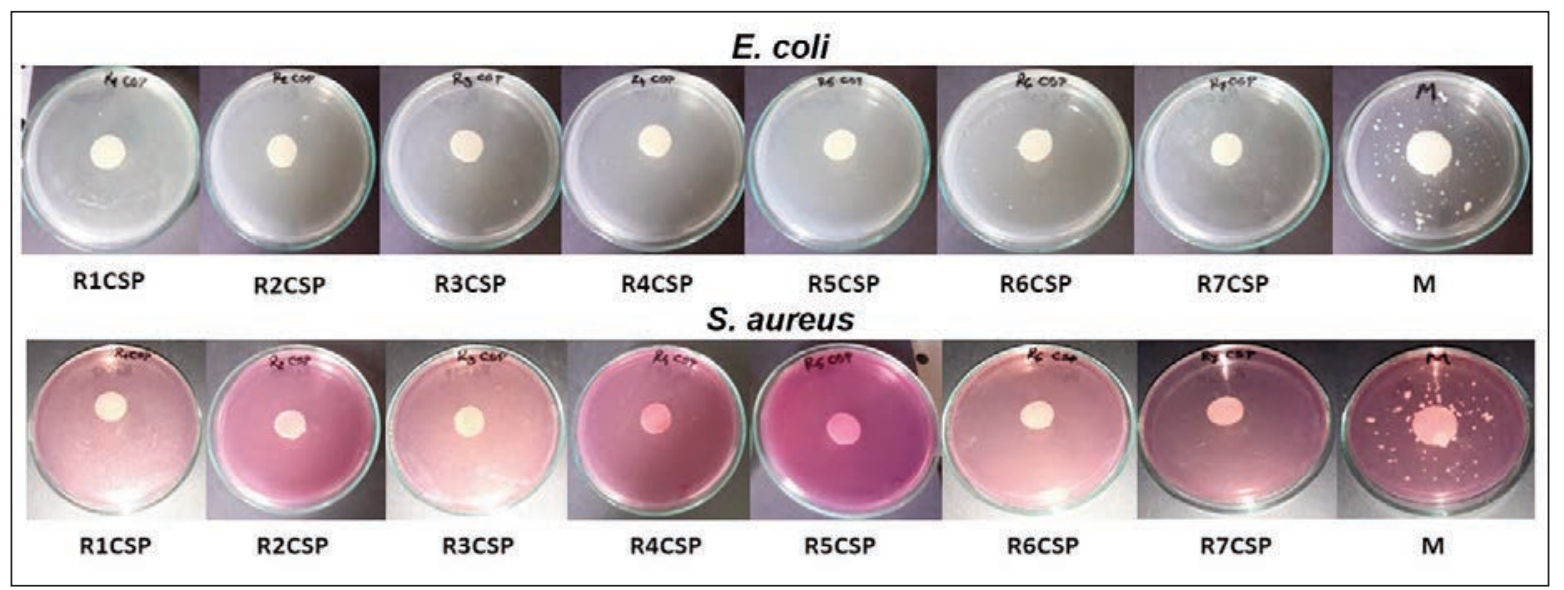

Fig. 5. Images of Petri plates showing antibacterial effect after $24 \mathrm{~h}$ of incubation

highest amount of active principle (R7CSP) having the smallest zone of inhibition $(1.5 \mathrm{~mm})$.

\section{CONCLUSIONS}

Seven exprimental variants of bioactive polymer systems synthesized based on chitosan-propolis-cinamon essential oil were assessed to explore their physico-chemical, biological as well as functional property to understand the possible applications in developing biomedical textiles. From the corroboration of the obtained data it was found that the obtained emulsions have a high degree of stability and a suitable viscosity to ensure a uniform deposition on the textile materials, on the one hand, and on the other hand to be able to be kept in a single phase until further application on textile materials. Textile materials treated with bioactive polymeric systems have shown antibacterial activity for both gram positive bacteria ( $S$. aureus) and gram negative bacteria (E. coli) test strains. The research on the potential bioactive polymeric systems based on chitosanpropolis-cinnamon for multifunctional properties development on textile materials is in progress.

\section{ACKNOWLEDGMENTS}

This work was carried out through the Nucleu Programme, with the support of MEC, project no. 4N/08.02.2019, PN 19 1703 01, project title: "Multifunctional integrated systems based on nanocomposites and pharmacodynamic therapeutic agents for different skin conditions - BIOPANTEX".

\section{REFERENCES}

[1] Subtirica, A.I., Banciu, C.A., Chivu, A.A.-M., Dinca, L.C., Nanofibres made from biocompatible and biodegradable polymers, with potential application as medical textiles, In: Industria Textila, 2018, 69, 1, 55-58, http://doi.org/ 10.35530/IT.069.01.1502

[2] Šauperl, O., Fras Zemljič, L., Volmajer Valh, J., Tompa, J., Textile cosmetic pads based on psyllium and protein colloid in combination with the horsetail extract, In: Industria Textila, 2019, 70, 1, 21-24, http://doi.org/ 10.35530/IT.070.01.1479

[3] Adomavičiūtè, E., Baltušnikaitè-Guzaitienè J., Juškaitè V., Žilius M., Briedisb V., Stanys, S., Formation and characterization of melt-spun polypropylene fibers with propolis for medical applications, In: The Journal of The Textile Institute, 2017, 109, 2, 278-284

[4] Najee, H., Kamerzan, C., Marutescu, L., Gheorghe. I., Popa, M., Grădișteanu, G., Lazăr, V., Antifungal activity of some medicinal plant extracts against Candida albicans nosocomial isolates, In: Romanian Biotechnological Letters, 2018, 23, 6, 14073-14076

[5] Shahid, M.Z., Saima, H., Yasmin, A., Nadeem, M.T., Imran, M., Afzaal, M., Antioxidant capacity of cinnamon extract for palm oil stability, In: Lipids in Health and Disease, 2018, 17, 116, https://doi.org/10.1186/s12944-018-0756-y

[6] Sharifan, A., Shafiee, M., Tabatabaee, A., Evaluation of antimicrobial effect of Cinnamomum verum methanolic extract and essential oil: a study on bio-preservative in ketchup sauce, In: J. Chem. Health Risks, 2016, 6, 2, 113-124

[7] Uchi, H., Yasumatsu, M., Morino-Koga, S., Mitoma C., Furue, M., Inhibition of aryl hydrocarbon receptor signaling and induction of NRF2-mediated antioxidant activity by cinnamaldehyde in human keratinocytes, In: J Dermatol Sci, $2017,85,1,36-43$

[8] Chuesiang, P., Siripatrawan U., Sanguandeekul, R., Yang, J.S., McClements, D.J., McLandsborough, L., Antimicrobial activity and chemical stability of cinnamon oil in oil-in-water nanoemulsions fabricated using the phase inversion temperature method, In: LWT - Food Science and Technology, 2019, 110, 190-196

[9] Cui, H., Li W., Li, C., Vittayapadung, S., Lin, L., Liposome containing cinnamon oil with antibacterial activity against methicillin-resistant Staphylococcus aureus biofilm, In: Biofouling, 2016, 32, 215-225 
[10] Fu, X.R., Shen, I., Jiang, X., Huang, D., Yan Y., Chitosan derivatives with dual-antibacterial functional groups for antimicrobial finishing of cotton fabrics, In: Carbohydrate Polymers, 2011, 85, 1, 221-227

[11] Bansal, V., Sharma, P.K., Sharma, N., Pal, P.O., Malviya R., Application of chitosan and chitosan derivatives in drug delivery, In: Advances in Biological Research, 2011, 5, 1, 28-37

[12] Rind, F.M.A., Memon, A.H., Almani, F., Laghari, M.G.H., Mughal, U.R., Maheshwari, M.L., Khuhawar, M.Y., Spectrophotometric determination of cinnamaldehyde from crude drugs and herbal preparations, In: Asian Journal of Chemistry, 2011, 23, 2, 631-635

Authors:

LAURA CHIRILĂ ${ }^{1}$, GABRIELA CRISTINA CONSTANTINESCU ${ }^{1}$, ANGELA DANILA², ALINA POPESCU ${ }^{1}$, ROXANA RODICA CONSTANTINESCU ${ }^{3}$, IRINA-MARIANA SĂNDULACHE ${ }^{1}$

${ }^{1}$ National Research and Development Institute for Textiles and Leather, 16 Lucretiu Patrascanu Street, 030508, Bucharest, Romania e-mail: office@incdtp.ro

2“Gheorghe Asachi” Technical University of lasi, Faculty of Industrial Design and Business Management, 29 Prof. Dr. Doc. Dimitrie Mangeron Blvd., 700050, lasi, Romania

${ }^{3}$ National Research and Development Institute for Textiles and Leather, Leather and Footwear Research Institute (ICPI) Division, 93, Ion Minulescu Street, 031215, Bucharest, Romania

Corresponding author:

ANGELA DANILA

e-mail: acerempei@tuiasi.ro 